Jurnal Al-Iqtishad Edisi 11 Volume 1 Tahun 2015

\title{
INVESTIGASI PERSEPSI MAHASISWA AKUNTANSI TERHADAP INTERNATIONAL FINANCIAL REPORTING STANDARDS
}

\author{
Jasmina Syafei \\ Fakultas Ekonomi dan Ilmu Sosial UIN Suska Riau \\ E-mail : jasmina_syafei@yahoo.co.id
}

\begin{abstract}
ABSTRAK
Penelitian ini adalah untuk menginvestigasi persepsi mahasiswa akuntansi terhadap International Financial Reporting Standars (IFRS). Hasilnya menunjukkan tidak terdapat perbedaan tingkat pengetahuan mahasiswa, terhadap pemahaman IFRS. Berdasarkan usia tidak terdapat perbedaan tingkat pengetahuan antar kelompok usia dalam memahami IFRS. Berdasarkan tahun masuk universitas, ada perbedaan tingkat pengetahuan mahasiswa terhadap pemahaman IFRS. Dalam analisis regresi tingkat pengetahuan berpengaruh negative dan signifikan terhadap keinginan untuk mengambil kelas tentang IFRS. Sedangkan untuk variabel INTEREST, minat berpengaruh positif dan signifikan terhadap keinginan mengambil kelas. Begitu pula dengan Persepsi mahasiswa mengenai dampak IFRS terhadap kinerja keuangan (PERCEPTION1) berpengaruh positif terhadap keinginan mengambil kelas. Sedangkan variabel PERCEPTION2, berkiatan dengan persepsi kinerja finansial akan menimbulkan keinginan untuk mengambil kelas terhadap IFRS. Namun hasil pengujian tidak signifikan Hasil yang serupa juga ditunjukkan oleh variabel PERCEPTION3, variabel persepsi mahasiswa mengenai pengaruh terhadap stakeholder tidak berpengaruh secara signifikan.
\end{abstract}

Kata kunci: Intent, Knowledge, Interest, Kinerja Kuangan, Kinerja Operasi, Stakeholder

\section{PENDAHULUAN}

\section{I.1. Latar Belakang Masalah}

Melaksanakan kegiatan usaha yang baik dengan tidak ada unsur riba, sesuai dengan kaidah-kaidah islam tentu kita telah melaksanakan sebagian dari ibadah. Namun dengan begitu masih harus adanya hal-hal yang mesti kita terapkan dalam kegiatan usaha seperti pencatatan kegiatan perusahaan. Islam juga mewajibkan bagi manusia agar selalu melakukan pencatatan dalam kegiatan transaksi antar sesama umat manusia. Hal itu dapat kita dapat ambil ilmunya dari surat al-baqarah ayat 282 yang artinya sebagai berikut

"Hai orang-orang yang beriman, apabila kamu bermu'amalah tidak secara tunai untuk waktu yang 
ditentukan, hendaklah kamu

diperlukan suatu standar menuliskannya. Dan hendaklah seorang penulis di antara kamu menuliskannya dengan benar. Dan janganlah penulis enggan menuliskannya sebagaimana Allah mengajarkannya, maka hendaklah ia menulis, dan hendaklah orang yang berhutang itu mengimlakkan (apa yang akan ditulis itu), dan hendaklah ia bertakwa kepada Allah Tuhannya, dan janganlah ia mengurangi sedikitpun daripada hutangnya. "(AlBaqarah:282)

Dari ayat Al Quran diatas, dapat diambil salah satu maknanya bahwa harus selalu dilakukan pencatatan dalam melakukan transaksi. Pencatatan tersebut harus dilakukan sesuai Prinsip Akuntansi yang Berterima Umum (PABU) agar para pengguna laporan keuangan dapat memahami Laporan Keuangan yang dihasilkan dari proses pencatatan tersebut. Di Indonesia, prinsip akuntansi yang berterima umum yang digunakan sebagai standar dalam pelaporan keuangan adalah Standar Akuntansi Keuangan (SAK) yang berisikan Pernyataan Standar Akuntansi Keuangan (PSAK).

$\begin{array}{cc}\text { International } & \text { Financial } \\ \text { Reporting } & \text { Standar }\end{array}$
merupakan standar tunggal pelaporan akuntansi yang memberikan tekanan pada penilaian kembali (revaluation) profesional dengan disclosures yang jelas dan transparan mengenai substansi ekonomi transaksi, penjelasan hingga mencapai kesimpulan tertentu. Standar ini muncul akibat tuntutan globalisasi yang mengharuskan para pelaku bisnis di suatu negara ikut serta dalam bisnis lintas negara. Untuk itu

internasional yang berlaku sama di semua negara untuk mempermudah proses rekonsiliasi bisnis.

Mengingat

tujuan

penyusunan standar akuntansi tersebut untuk dapat dipergunakan sebanyak mungkin negara di dunia maka dalam penyusunan standar akuntansi tertentu Badan Standar Akuntansi mempertimbangkan kondisi sebagian besar negara sehingga sesuai dengan kebutuhan mereka.

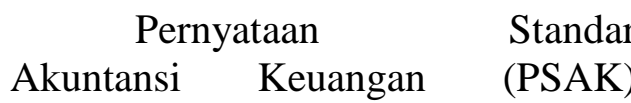
merupakan standar yang digunakan untuk menyusun laporan keuangan perusahaan yang memiliki akuntabilitas publik signifikan. BUMN termasuk perusahaan yang memiliki akuntabilitas publik signifikan karena laporannya diberikan kepada masyarakat. Untuk BUMN yang memiliki transaksi syariah juga harus menggunakan PSAK Syariah untuk melaporkan transaksi tersebut.

PSAK baru yang mengadopsi penuh IFRS efektif berlaku mengikuti keluarnya PSAK tersebut. Mulai tahun 2008 PSAK tersebut sudah ada yang mulai efektif berlaku. Sementara ada beberapa PSAK yang baru efektif berlaku 2012. Bahkan saat ini masih ada beberapa IFRS yang belum dikeluarkan exposure draftnya contohnya IFRS 1 Full Adoption dan IAS 41 Biological Asset. Setelah tahun 2012 proses adopsi akan tetap secara konsisten dilakukan, karena PSAK baru yang diterbitkan didasarkan pada IFRS yang saat itu telah ada. Ada beberapa PSAK yang telah diadopsi, IFRSnya telah 
direvisi, misalnya PSAK 23 Pendapatan. IFRS sebagai standar yang berlaku secara global, menyangkut kepentingan banyak pihak, sehingga penerapan standar yang menimbulkan masalah akan dikritisi sehingga akan dinamis dengan perubahan.

Kristanti， dkk. (2013) mengatakan pengetahuan akan IFRS penting bagi mahasiswa program studi akuntansi. Menurut James (2011) pengetahuan yang baik akan IFRS akan memberikan berbagai keuntungan seperti: (1) performa yang lebih baik pada ujian sertifikasi Certified Public Accountant (CPA exam), dimana pertanyaan mengenai IFRS akan dimuat pada test tersebut. (2) kesempatan yang lebih besar bekerja pada perusahaan multinasional, baik accounting firms maupun non accounting firms. Kroll (2009) dalam Bandyopadhyay dan McGee (2012) menyatakan bahwa KAP big four bahkan mensyaratkan karyawan yang baru untuk paham IFRS, sedangkan KAP regional juga mengharapkan karyawan tahu tentang standar tersebut pada suatu level tertentu. Lulusan akuntansi yang mememiliki pengetahuan yang baik terhadap IFRS memiliki keunggulan kompetitif saat rekruitmen karyawan.

Mahasiswa akuntansi harus memiliki kemampuan untuk membedakan proses pelaporan keuangan antara Generally Accepted Accounting Principles (GAAP) dan standard internasional lainnya (The National Business Education Association Standards, 2007). Khususnya di Indonesia mahasiswa akuntansi perlu memahami perbedaan PSAK dan
IFRS karena saat ini Indonesia sedang berada pada tahap konvergensi.

Dari latar belakang masalah tersebut, maka dilakukan penelitian serupa dengan responden yang berbeda dan waktu yang berbeda. Responden penelitian ini diambil dari mahasiswa jurusan Akuntansi Fakultas Ekonomi dan Ilmu sosial UIN Suska Riau. Penelitian serupa pernah dilakukan oleh Kim (2011) dan Kristanti, dkk. (2013).

\section{HASIL DAN PEMBAHASAN Pemahaman IFRS}

Salah satu fenomena global saat ini dalam dunia akuntansi adalah konvergensi IFRS. Indonesia direncanakan mengadopsi penuh IFRS pada tahun 2012. Menurut Ketua Dewan Standar Akuntansi Keuangan Ikatan Akuntan Indonesia (IAI) tujuan konvergensi IFRS ini adalah agar laporan keuangan yang berdasarkan Pernyataan Standar Akuntansi Keuangan (PSAK) tidak memerlukan rekonsiliasi dengan laporan berdasarkan standar internasional. Diharapkan konvergensi IFRS ini nantinya akan dapat meningkatkan kegiatan investasi dan memperkecil cost of capital serta meningkatkan transparansi laporan keuangan. Selain itu ada beberapa dampak lain yang akan ditimbulkan dari program konvergensi IFRS ini antara lain:

1. Akses pendanaan internasional akan lebih terbuka.

2. Relevansi laporan keuangan akan meningkat karena penggunaan fair value.

3. Income Smoothing dapat diminimalisir dengan penggunaan balance sheet approach. 
4. Penggunaan off balance sheet semakin terbatas.

Dengan adanya beberapa perubahan dalam Standar Akuntansi yang nantinya akan digunakan oleh perusahaan - perusahaan maka diperlukan akuntan - akuntan yang mengerti dan memahami IFRS. Lahirnya akuntan professional adalah dari suatu perguruan tinggi yang terus mengembangkan mutu pendidikannya. Ada beberapa cara dalam meningkatkan mutu tersebut yaitu dengan peningkatan sarana pendidikan dan pengembangan kecerdasan emosional dalam diri setiap individu yang ada dalam perguruan tinggi tersebut, baik Guru Besar, Dosen, Karyawan maupun Mahasiswa.

\section{Tingkat Pengetahuan}

Pengetahuan merupakan hasil dari tahu dan ini terjadi setelah orangmelakukan engindraan terhadap suatu objek tertentu. Pengindraan terjadi melalui pancaindra manusia, yakni indra penglihatan, pendengaran, penciuman, rasa, dan raba. Sebagian besar pengetahuan manusia diperoleh melalui mata dan telinga. Pengetahuan atau kognitif merupakan domain yang sangat penting dalam membentuk tindakan seseorang (over behavior) (Notoatmodjo, 2007). Tahu diartikan sebagai mengingat suatu materi yang telah dipelajari sebelumnya. Termasuk ke dalam pengetahuan ini adalah mengingat kembali (recall) rangsangan yang telah diterima. Oleh sebab itu, ini merupakan tingkat pengetahuan yang rendah. Kata kerja untuk mengukur bahwa orang tahu tentang apa yang dipelajari antara lain menyebutkan, mendefinisikan, menyatakan dan sebagainya.(Notoatmodjo, 2003).

\section{Minat}

Penelitian Napitupulu (2008) menyatakan bahwa minat tidak mampu memoderasi kecerdasan emosional terhadap tingkat pemahaman akuntansi. Penelitian tersebut menjadi dasar dalam pengujian ulang pengaruh minat sebagai variabel moderating. Berikut beberapa definisi mengenai minat :

a. Skinner (dalam Muhlasin; 2006) mengemukakan bahwa minat merupakan motif yang menunjukan arah perhatian individu terhadap objek yang menarik, yaitu objek yang menyenangkan.

b. Asher, Tiffin, dan Knight (dalam Bunga Bangsaku, 2008) mengartikan minat sebagai sikap atau kondisi psikologis yang ditandai dengan pemusataan perhatian terhadap masalah-masalah atau aktivitas tertentu atau sebagai kecenderungan untuk memahami suatu pengalaman dan akan selalu diulang.

c. Chaplin memberikan definisi minat sebagai suatu pernyataan yang menyatakan bahwa satu aktivitas, pekerjaan, atau obyek itu berharga atau berarti bagi individu.

d. Crow dan Crow (dalam bintang bangsaku, 2008) mengemukakan minat atau interest adalah merupakan kekuatan individu yang menyebabkan individu memberikan perhatian pada orang, benda atau aktivitas.

Factor-faktor yang mendasari timbulnya minat adalah :

1) Faktor dorongan dalam; dorongan dari individu itu sendiri, sehingga timbul minat untuk melakukan 
aktivitas atau tindakan tertentu untuk memenuhinya. Misalnya untuk dorongan makan, menimbulkan minat untuk mencari makanan

2) Faktor motivasi sosial; faktor ini merupakan faktor untuk melakukan suatu aktivitas agar dapat diterima dan diakui oleh lingkungannya. Minat ini merupakan semacam kompromi pihak individu dengan lingkungan sosialnya. Misalnya minat pada studi karena ingin mendapatkan penghargaan dari orang tuanya.

3) Faktor emosional; minat erat hubungannya dengan emosi karena faktor ini selalu menyertai seseorang dalam berhubungan dengan obyeknya minatnya. Kesuksesan seseorang pada suatu aktivitas disebabkan karena aktivitas tersebut menimbulkan perasaan suka atau puas, sedangkan kegagalan akan menimbulkan perasaan tidak senang dan mengurangi minat seseorng terhadap kegiatan ybs.

\section{Kinerja Keuangan}

$\begin{array}{rr}\text { Kinerja } & \text { perusahaan } \\ \text { merupakan hasil dari banyak }\end{array}$ keputusan individu yang

dibuat secara terus menerus oleh pihak manajemen suatu perusahaan. Kinerja berarti pula bahwa dengan masukan tertentu untuk memperoleh keluaran tertentu. Secara implisit definisi kinerja mengandung suatu pengertian adanya suatu efisiensi yang dapat diartikan secara umum sebagai rasio atau perbandingan antara masukan dan keluaran. Kinerja perusahaan sebagai emiten di pasar modal merupakan prestasi yang dicapai perusahaan yang menerbitkan saham yang mencerminkan kondisi keuangan dan hasil operasi (operating result) perusahaan tersebut dan biasanya diukur dalam rasio-rasio keuangan (Siregar, 2010). Menurut Fabozzi (1999) dalam Siregar (2010), kinerja suatu perusahaan dipengaruhi oleh berbagai faktor yang secara umum dapat dibagi dalam dua kelompok, yaitu faktor internal dan faktor eksternal perusahaan. Faktor internal merupakan faktor-faktor yang berada dalam kendali pihak manajemen perusahaan, sedangkan faktor eksternal merupakan faktor-faktor yang berada di luar kendali manajemen perusahaan.

\section{Faktor Eksternal}

a) Kondisi perekonomian

Kondisi yang dipengaruhi kebijakan pemerintah, keadaan dan stabilitas politik, ekonomi, sosial, dan lain-lain.

b) Kondisi Industri

Meliputi tingkat persaingan, jumlah perusahaan, dan lain-lain. Pengukuran kinerja perusahaan dengan menggunakan ukuran rasio sudah menjadi suatu parameter yang terbilang umum saat ini. Dalam penelitian-penelitian yang berkaitan dengan penilaian kinerja perusahaan dilakukan berdasarkan pada ketentuan: (1) hasil penelitianpenelitian sejenis sebelumnya, (2) menggunakan tolok ukur yang telah ditetapkan oleh otoritas yang berwenang, (3) kelaziman dalam praktek, (4) mengembangkan model pengukuran melalui pengujian secara statistik terlebih dahulu dengan memilih tolok ukur yang sesuai dengan tujuan penelitian.

Sawir (2005) menyatakan bahwa kinerja keuangan adalah prestasi yang dicapai oleh 
perusahaan dalam suatu periode tertentu yang mencerminkan tingkat kesehatan dari perusahaan tersebut. Nainggolan (2004) dalam Christiani (2010) menyatakan bahwa kinerja keuangan perusahaan merupakan salah satu aspek penilaian yang fundamental mengenai kondisi keuangan perusahaan yang dapat dilakukan berdasarkan analisis terhadap rasio-rasio keuangan perusahaan, antara lain : rasio likuiditas, rasio leverage, rasio aktivitas dan rasio profitabilitas yang dicapai oleh perusahaan dalam suatu periode tertentu.

Harmanto (1992) dalam

Raharjo (2005) melalui laporan keuangan dapat diperoleh informasiinformasi yang penting suatu perusahaan yaitu berupa:

a) Informasi tentang sumber-sumber ekonomi dan kewajiban serta modal perusahaan.

b) Informasi mengenai sumbersumber ekonomi, harta atau kekayaan bersih yang timbul dalam aktivitas perusahaan dalam rangka memperoleh laba.

c) Informasi mengenai hasil usaha perusahaan yang dapat dipakai sebagai dasar untuk menilai dan membuat estimasi tentang kemampuan perusahaan dalam menghasilkan laba.

d) Informasi mengenai perubahan dalam sumber-sumber ekonomi dan kewajiban yang disebabkan oleh aktivitas pembelanjaan dan investasi.

e) Informasi penting lainnya yang berhubungan dengan laporan keuangan seperti kebijakan akuntansi yang diterapkan di perusahaan.

\section{Kerangka Pemikiran dan Perumusan Hipotesis}

\begin{abstract}
Hong (2008) melakukan penelitian di Hong Kong, yang dilakukan terhadap mahasiswa akuntansi tahun ketiga. Hasilnya menunjukkan bahwa gender berpengaruh secara signifikan terhadap performa mahasiswa akuntansi dalam studi pada tingkat strata $1 \quad(\mathrm{H}$ o, 2008). Menurut Stivers dan Onifade (2011), perempuan memiliki technical skill dalam bidang akuntansi lebih baik daripada laki-laki, sehingga terdapat kemungkinan lebih tinggi untuk lebih mudah mengadopsi IFRS sebagai standar yang baru. Cudia (2009) melakukan penelitian tentang performa mahasiswa pada matakuliah akuntansi manajemen. Penelitian ini menunjukkan bahwa mahasiswa perempuan lebih teliti sehingga memiliki nilai yang lebih baik dari pada mahasiswa laki-laki, walaupun IQ pada mahasiswa lakilaki memiliki rata-rata yang lebih tinggi.
\end{abstract}

Dari penelitian-penelitian tersebut dapat dirumuskan hipotesis sebagai berikut:

H1: Terdapat perbedaan tingkat pengetahuan mahasiswa laki-laki dan perempuan terhadap pemahaman IFRS.

Penelitian yang dilakukan Koh \& Koh (1999) menunjukkan bahwa usia memiliki pengaruh signifikan terhadap performa di bidang akuntansi. Terdapat koefisien negatif yang mengindikasikan bahwa mahasiswa dengan usia yang lebih muda memiliki performa yang lebih baik. Akan tetapi Kim (2011) membuktikan bahwa tidak terdapat perbedaan tingkat pengetahuan terhadap IFRS berdasarkan 
kelompok usia. Dari hasil yang tidak konsisten tersebut, maka dapat dirumuskan hipotesis :

H2: Terdapat perbedaan tingkat pengetahuan mahasiswa terhadap pemahaman IFRS berdasarkan usia.

Kim (2011) menemukan bahwa tidak terdapat perbedaan berkaitan dengan pengetahuan terhadap IFRS berdasarkan tahun masuk universitas. Sebaliknya, di UKSW pengintregasian IFRS pada materi akuntansi keuangan baru dimulai pada semester genap tahun ajaran 2010/2011, sehingga dapat diasumsikan mahasiswa dengan tahun masuk 2010,2011 dan 2012 mendapat materi yang bermuatan IFRS lebih banyak dibanding dengan angkatan sebelumnya. Hal ini dapat mendorong perbedaan tingkat pengetahuan berdasarkan tahun masuk universitas, sehingga dapat dirumuskan hipotesis sebagai berikut:

H3: Terdapat perbedaan tingkat pengetahuan mahasiswa terhadap pemahaman IFRS berdasarkan tahun masuk universitas.

Kim (2011) melakukan penelitian tentang beberapa faktor yang mempengaruhi keinginan mahasiswa mengambil kelas tentang IFRS apabila universitas menawarkannya. Pertama, ditemukan pengaruh negatif mengenai tingkat pengetahuan terhadap keinginan mengambil kelas. Mahasiswa yang merasa telah menguasai materi tentunya merasa tidak perlu mengambil kelas khusus. Kedua, minat berpengaruh positif dan signifikan terhadap keinginan mengambil kelas. Semakin tinggi minat semakin tinggi pula rasa ingin tahu, yang pada akhirnya dilakukan pengambilan kelas sebagai salah satu cara untuk memenuhi keingintahuan.

Ketiga, ditemukan persepsi mengenai pengaruh standar tersebut pada kinerja keuangan berpengaruh negatif dan signifikan pada keputusan pengambilan kelas. Sebaliknya, ditemukan pengaruh positif pada persepsi mengenai pengaruh IFRS pada kinerja operasi dan stakeholder. Ketika mahasiswa menyadari bahwa standar tersebut memiliki banyak pengaruh, maka terdapat dorongan untuk menguasainya. Dari uraian di atas dapat ditarik hipotesis sebagai berikut:

H4a: Tingkat pengetahuan berpengaruh negatif terhadap keinginan untuk mengambil kelas tentang IFRS.

H4b: Minat pada IFRS berpengaruh positif terhadap keinginan untuk mengambil kelas tentang IFRS.

H4c: Persepsi mengenai pengaruh IFRS terhadap kinerja keuangan berpengaruh negative terhadap keinginan untuk mengambil kelas tentang IFRS.

H4d: Persepsi mengenai pengaruh IFRS terhadap kinerja operasi berpengaruh positif terhadap keinginan untuk mengambil kelas tentang IFRS.

H4e: Persepsi mengenai pengaruh IFRS terhadap pemangku kepentingan (stakeholder) berpengaruh positif terhadap 
keinginan untuk mengambil kelas tentang IFRS.

\section{Metode Penelitian \\ Populasi dan Sampel}

Populasi adalah kumpulan dari keseluruhan elemen yang menjadi pusat objek penelitian (Indriantoro dan Supomo, 2009). Populasi dalam penelitian adalah mahasiswa jurusan Akuntansi Fakultas Ekonomi dan Ilmu sosial UIN Suska Riau. Pemilihan sampel penelitian ini menggunakan metode disproportionate stratified random sampling yaitu mahasiswa secara acak diambil dari kategori-kategori tertentu berdasarkan usia, tahun masuk, dan gender tanpa memperhatikan proporsi dari setiap kategori tersebut. Hal tersebut didasarkan pada asumsi mahasiswa angkatan 2009 dan 2010 sebagian telah menyelesaikan studinya. Sampel penelitian berjumlah 200 mahasiswa jurusan Akuntansi Fakultas Ekonomi dan Ilmu sosial UIN Suska Riau.

\section{Definisi variabel dan metode riset Peneltian ini untuk menginvestigasi persepsi terhadap pengadopsian IFRS pada mahasiswa. Variabel yang digunakan sebanyak 6 variabel, yaitu sebagai berikut:}

1. INTENT: variabel yang menunjukkan keinginan mahasiswa untuk mengambil kelas tentang IFRS.

2. KNOWLEDGE: tingkat pengetahuan terhadap IFRS yang diukur berdasarkan mahasiswa mempersepsikan tingkat pengetahuannya sekarang.
3. INTEREST: variabel yang menunjukkan minat mahasiswa terhadap IFRS.

4. PERCEPTION 1: persepsi mahasiswa tentang apakah IFRS memiliki pengaruh terhadap kinerja keuangan.

5. PERCEPTION 2: persepsi mahasiswa tentang apakah IFRS memiliki pengaruh terhadap kinerja operasi.

6. PERCEPTION 3: persepsi mahasiswa tentang apakah IFRS mempengaruhi pemangku kepentingan (stakeholder) seperti investor dan pemegang saham.

\section{Metode Analisis Statistik}

\section{Statistika inferensial}

\section{Uji beda (t-test)}

Uji $t$ (t-test) merupakan prosedur pengujian parametrik ratarata dua kelompok data, baik untuk kelompok data terkait maupun dua kelompok bebas. Untuk jumlah data yang sedikit maka perlu dilakukan uji normalitas untuk memenuhi syarat dari sebaran datanya. Umumnya pada uji t dua kelompok bebas, yang perlu diperhatikan selain normalitas data juga kehomogenan varian. Kehomogenan data digunakan untuk menentukan jenis persamaan uji $t$ yang akan digunakan. Uji beda dilakukan pada tingkat $\alpha 0.05$.

\section{Analysis of Varians (ANOVA)}

ANOVA Merupakan prosedur pengujian parametrik ratarata lebih dari dua kelompok data. Pada pengujian Anova selain data harus terdistribusi normal, variansi antar perlakuan harus homogen. Sebelum pengujian Anova 
dilakukan, maka perlu dilakukan explorasi data untuk melihat apakah kedua asumsi dipenuhi. Jika asumsi kehomogenan varian tidak terpenuhi dapat diatasi dengan mentransformasi data yang ada. Pada uji Anova umumnya diikuti oleh uji lanjutan berupa uji Turkey (Beda Nilai Jujur), Beda Nilai Terkecil (BNT), Benferoni dll. Penggunaan jenis uji lanjutan didasarkan pada pemenuhan asumsi ke homogenan variansi serta tingkat sensitifitasan dari pengujian.

Untuk mengukur perbedaan varians tingkat pengetahuan pada karakteristik dengan beberapa populasi digunakan ANOVA (Analysis of Variance). ANOVA dilakukan pada karakteristik usia dan tahun masuk. ANOVA juga diuji pada tingkat $\alpha 0.05$.

\section{Uji Regresi Berganda}

Analisis Regresi Linear Berganda digunakan untuk mengukur pengaruh antara lebih dari satu variabel prediktor (variabel bebas) terhadap variabel terikat.

Adapun hipotesis yang akan diuji secara parsial adalah sebagai berikut:

H4a: pengetahuan berpengaruh negatif terhadap keinginan untuk mengambil kelas tentang IFRS.

H4b: Minat pada IFRS berpengaruh positif terhadap keinginan untuk mengambil kelas tentang IFRS.

H4c: Persepsi mengenai pengaruh IFRS terhadap kinerja keuangan berpengaruh negative terhadap keinginan untuk mengambil kelas tentang IFRS.

H4d: Persepsi mengenai pengaruh IFRS terhadap kinerja operasi berpengaruh positif terhadap keinginan untuk mengambil kelas tentang IFRS.

H4e: Persepsi mengenai pengaruh IFRS terhadap pemangku kepentingan (stakeholder) berpengaruh positif terhadap keinginan untuk mengambil kelas tentang IFRS.

\section{T-test dan ANOVA (Analysis of Variance)}

Seperti yang dapat dilihat pada Tabel 5, ditemukan hasil ratarata tingkat pengetahuan pada pria (dinotasikan dengan 1) adalah 2,5577, sedikit lebih rendah daripada wanita (dinotasikan dengan 2) yang hanya sebesar 2,5806 . Akan tetapi perbedaan tersebut tidak signifikan karena signifikansi uji $\mathrm{t}$ sebesar 0,356 ( $\mathrm{p}$-value>0.05). Hasil tersebut sekaligus menolak $\mathrm{H} 1$ dimana tidak terdapat perbedaan tingkat pengetahuan mahasiswa terhadap IFRS berdasarkan gender.Penelitian ini memiliki hasil yang tidak konsisten dengan penelitian yang dilakukan Ho (2008), Stivers dan Onifade (2011) dan Cudia (2009). Hal ini diperkuat dengan membandingkan komentar yang diberikan oleh responden pria maupun wanita. Komentar yang diberikan hampir sama yaitu pemahaman IFRS adalah hal yang penting untuk mahasiswa akuntansi. Kesamaan tingkat pengetahuan ini kemungkinan dipengaruhi oleh input pengetahuan terhadap IFRS dalam porsi yang sama, karena baik pria dan wanita diwajibkan mengambil kelas akuntansi keuangan yang sama.

Berdasarkan usia ditemukan tingkat pengetahuan tertinggi dengan mean sebesar 2,6056 ada pada 
kelompok usia 21 s.d 30 tahun, dan dibawahnya kelompok umur kurang dari 20 tahun dengan nilai mean 2,5588. Pada uji tersebut ditemukan nilai $\mathrm{F}=0.466$ dan $\mathrm{p}$-value $>0.05$, sehingga varians antar populasi dianggap sama. Hasil tersebut sekaligus menolak $\mathrm{H} 2$, dimana tidak terdapat perbedaan tingkat pengetahuan antar kelompok usia. Temuan ini konsisten dengan penelitian yang dilakukan Kim (2011).

Terhadap pengujian hipotesis ke 3 yaitu terdapat perbedaan tingkat pengetahuan mahasiswa terhadap IFRS berdasarkan tahun masuk universitas. Dalam penelitian ini diperoleh tiga katagori kelompok semester mahasiswa yiatu semester 3 sebanyak 95 orang, semester 5 sebanyak 76 orang dan dan semester 7 sebanyak 36 orang.

Karena terdapat tiga katagori, maka uji hipotesis dilakukan dengan menggunakan levene's test of homogeneity of variance untuk menguji asumsi Anova bahwa setiap group (katagori) variabel independen memiliki varian sama.

Hasil uji levence test menunjukkan bahwa nilai $\mathrm{F}$ test sebesar 0,468 dengan signifikansi 0,627 , lebih besar dari 0,05 ( $p>0,05$ ) yang berarti kita tidak dapat menolak hipotesis nol yang menyatakan varian sama, yaitu tidak ada perbedaan tingkat pengetahuan mahasiswa terhadap IFRS berdasarkan tahun masuk universitas.

Hasil ANOVA ini tidak konsisten dengan penelitian sebelumnya dan sekaligus menolak H3. Hal ini dapat disebabkan dikarenakan pada masa angkatan 2011, 2012, dan 2013, pengajar tidak banyak menyinggung IFRS. Sebagai akibatnya, angkatan mereka samasama tidak memiliki kemampuan yang cukup mengenai standar ini. Seorang responden bahkan berpendapat bahwa dia dan beberapa temannya yang akan lulus sering mendengar tentang IFRS. Akan tetapi latar belakang, implementasi, perbedaan dengan standar sebelumnya dan hal-hal lain yang lebih dalam belum mereka ketahui secara penuh. Hal ini mengakibatkan kekuatiran ketika mahasiswa tersebut berharap akan bekerja pada multinational company atau accounting firm.

\section{Uji Regresi Berganda}

Untuk mengetahui variabelvariabel yang mempengaruhi keinginan mahasiswa untuk mengambil kelas tentang IFRS dilakukan analisis regresi berganda. Selanjutnya untuk menguji hipotesis (H4) disusunlah model sebagai berikut:

INTENT $=\beta 0+\beta 1$ KNOWLEDGE

$\begin{array}{llll}+ & \beta 2 \text { INTEREST } & + & \beta 3 \\ \text { PERCEPTION1 } & + & \beta 4 \\ \text { PERCEPTION2 } & + & & \beta 5\end{array}$
PERCEPTION3

Tabel 4 menunjukkan hasil analisis regresi berganda. Pada variabel KNOWLEDGE ditemukan nilai $\mathrm{t}=-3,855$ dan $\mathrm{p}$-value $<0.05$, temuan ini konsisten dengan hipotesis penelitian ini dan menerima $\mathrm{H} 4 \mathrm{a}$. Artinya tingkat pengetahuan berpengaruh negatif dan signifikan terhadap keinginan untuk mengambil kelas tentang IFRS. Hasil ini didukung oleh responden yang menyatakan bahwa ketika seorang mahasiswa merasa menguasai materi IFRS maka mahasiswa tersebut 
merasa tidak perlu mengambil kelas khusus.

Tabel 4.9.

Hasil uji hipotesis

\section{Coefficients $^{\mathrm{a}}$}

\begin{tabular}{|c|c|c|c|c|c|c|}
\hline \multirow{2}{*}{\multicolumn{2}{|c|}{ Model }} & \multicolumn{2}{|c|}{$\begin{array}{c}\text { Unstandardized } \\
\text { Coefficients }\end{array}$} & \multirow{2}{*}{$\begin{array}{c}\begin{array}{c}\text { Standardized } \\
\text { Coefficients }\end{array} \\
\text { Beta }\end{array}$} & \multirow[b]{2}{*}{$\mathrm{T}$} & \multirow[b]{2}{*}{ Sig. } \\
\hline & & B & Std. Error & & & \\
\hline \multirow[t]{6}{*}{1} & (Constant) & 4.727 & .673 & & 7.022 & .000 \\
\hline & prsps_knwldg & -.222 & .120 & -.124 & -3.855 & .035 \\
\hline & Interest & .349 & .112 & .212 & 3.128 & .002 \\
\hline & prsp_prcept1 & .315 & .156 & .159 & 2.020 & .045 \\
\hline & prsp_prcept2 & .120 & .162 & .062 & .744 & .458 \\
\hline & prsp_prcept3 & .231 & .135 & .129 & 1.711 & .089 \\
\hline
\end{tabular}

a. Dependent Variable: tot_inten

Untuk variabel INTEREST, didapat nilai $\mathrm{t}=3,128$ dan $\mathrm{p}$ value $<0.05$. Minat berpengaruh positif dan signifikan terhadap keinginan mengambil kelas. Semakin tinggi minat mahasiswa terhadap IFRS semakin tinggi keinginan mahasiswa mengambil kelas terhadap IFRS. Hasil statistik menunjukkan konsistensi terhadap Kim (2011) dan menerima H4b. Minat menjadi faktor penting yang mempengaruhi keputusan tersebut, mahasiswa yang tertarik akan memiliki keinginan belajar yang lebih tinggi dibandingkan mahasiswa yang tidak memiliki minat.

$$
\text { Persepsi mahasiswa }
$$

mengenai dampak IFRS terhadap kinerja keuangan (PERCEPTION1) berpengaruh positif terhadap keinginan mengambil kelas. Dan pengaruh signifikan $(t=2,020$ dan $p$ - value>0.05). Pernyataan ini konsisten dengan penelitian Kim (2011) dan menerima H4c. Selanjutnya ditemukan nilai $\beta=0,120$ pada variabel PERCEPTION2, sehingga setiap kenaikan 1 level dari persepsi tentang kinerja finansial akan mengakibatkan kenaikan sebesar $12 \%$ pada keinginan untuk mengambil kelas terhadap IFRS. Namun kenaikan tersebut dianggap tidak signifikan $(\mathrm{t}=0.744$ dan $\mathrm{p}$ value>0.05). Hasil ini konsisten dengan penelitian Kim (2011) dan menolak H4d. Hasil yang serupa juga ditunjukkan oleh variabel PERCEPTION3, ditemukan koefisien negatif pada variabel ini $(\beta=-1,711)$. Secara parsial variabel persepsi mahasiswa mengenai pengaruh terhadap stakeholder tidak berpengaruh secara signifikan. 
Hasil tersebut konsisten dengan penelitian Kim (2011) dan menolak H4d. Pada ketiga variabel PERCEPTION didapat hasil yang tidak signifikan secara parsial. Meskipun mahasiswa tahu akan pengaruh yang ditimbulkan akibat konvergensi standar yang baru, tidak menjadikan motivasi untuk mengambil kelas. Kemungkinan hal ini terjadi karena mahasiswa kurang peduli dengan pengaruh IFRS di luar ranah pendidikan akan membawa dampak besar pada mahasiswa.

\section{Koefesien Determinasi}

Koefisien determinasi $\left(\mathrm{R}^{2}\right)$ sebesar 0,38, ini berarti $38 \%$ keinginan mahasiswa untuk mengambil kelas tentang IFRS dapat dijelaskan oleh kelima variabel bebas. Sedangkan $62 \%$ sisanya dapat dijelaskan oleh variabel-variabel lain di luar model.

\section{PENUTUP}

Berdasarkan hasil analisis data dan pembahasan yang telah diuraikan, dapat disimpulkan sebagai berikut:

1. Ditemukan hasil rata-rata tingkat pengetahuan pada pria adalah 2,5577, sedikit lebih rendah daripada wanita yang hanya sebesar 2,5806. Akan tetapi perbedaan tersebut tidak signifikan karena signifikansi uji t sebesar 0,356 ( $\mathrm{p}$-value>0.05). Hasil tersebut sekaligus menolak H1 dimana tidak terdapat perbedaan tingkat pengetahuan mahasiswa terhadap pemahaman IFRS

2. Berdasarkan usia ditemukan nilai $\mathrm{F}=0.466$ dan $\mathrm{p}$-value $>0.05$, sehingga varians antar populasi dianggap sama. Hasil tersebut sekaligus menolak $\mathrm{H} 2$, dimana tidak terdapat perbedaan tingkat pengetahuan antar kelompok usia dalam memahami IFRS. Temuan ini konsisten dengan penelitian yang dilakukan Kim (2011).

3. Berdasarkan tahun masuk universitas, hasil uji levence test menunjukkan bahwa nilai $\mathrm{F}$ test sebesar 0,468 dengan signifikansi 0,627, lebih besar dari 0,05 ( $>>0,05)$ yang berarti kita tidak dapat menolak hipotesis nol yang menyatakan varian sama, yaitu tidak ada perbedaan tingkat pengetahuan mahasiswa terhadap pemahaman IFRS berdasarkan tahun masuk universitas.

4. Terhadap hasil analisis regresi berganda, tingkat pengetahuan berpengaruh negatif dan signifikan terhadap keinginan untuk mengambil kelas tentang IFRS. Untuk variabel INTEREST, minat berpengaruh positif dan signifikan terhadap keinginan mengambil kelas.

5. Persepsi mahasiswa mengenai dampak IFRS terhadap kinerja keuangan (PERCEPTION1) berpengaruh positif terhadap keinginan mengambil kelas.

6. Terhadap variabel PERCEPTION2, berkaitan dengan persepsi kinerja finansial akan menimbulkan keinginan untuk mengambil kelas terhadap IFRS. Namun hasil pengujian tidak signifikan

7. Hasil yang serupa juga ditunjukkan oleh variabel PERCEPTION3, variabel persepsi mahasiswa mengenai pengaruh 
terhadap stakeholder tidak berpengaruh secara signifikan.

\section{Keterbatasan dan saran}

Pada penelitian ini terdapat batasan yang ditemukan. Pertama, dari sisi responden sebesar 207 orang sangat minim jumlahnya, sehingga responden harus di tambah lebih besar lagi agar diperoleh hasil penelitian yang lebih dapat digeneralisasikan secara luas. Selain itu sampel penelitian diambil dari satu universitas saja yaitu Universitas Islam Negeri Sultan

\section{DAFTAR PUSTAKA}

Ahmed, K., and M. Alam. 2012. The Effect of IFRS Adoption on the Financial Repor ts of Local Government Entities, Australasian Accounting Business \& Finance Journal 6(3): 109-120.

Albu, N., C. N. Albu., and M. M. Girbina. 2012. Educating Accounting Students in an Emerging Market Economy - An Analysis of the Importance of Stereotypes in Teaching IFRS, International Journal of Academic Research 4(3): 51-57.

Bandyopadhyay, J., and P. F. McGee. 2012. A Progress Report: IFRS-U.S. GAAP Convergence and Its Curriculum Impact, Advances in Competitiveness Research 20(1/2): 78-89.

Berita Sore.com (2009). Indonesia Berlakukan Standar
Syarif Kasim Riau. Ada baiknya cakupan pemerolehan data diperluas ke beberapa perguruan tinggi lainnya.

\section{Rekomendasi}

Dengan melihat hasil penelitian ini, diharapkan dapat dijadikan informasi sebagai pertimbangan dan evaluasi terkait kebijakan kurikulum maupun penawaran kelas mengenai standar tersebut.

Konvergensi Akuntansi IFRS 2012.

Bohusova, H., and D. Nerudova. 2009. US GAAP and IFRS Convergence in the Area of Revenue Recognition, Economics\& Management : 12-19.

Buys, P. W., D. Schutte., and P. Andrikopoulos. 2012. Understanding Accounting Students Cultural Diversity and Its Implication of the Interpretation of IFRS, International Business \& Economics Research Journal 11(4): 451-466.

Cohen, S., and S. Karatzimas. 2012. Has IFRS Adoption Affected Management Accounting System? Empirical Evidence from Greece, Social Science Research Network Maret.

Cudia, C. P. 2009. Factors That Influence The Final Grades of Students in Managerial Accounting Course in De La Salle University, Journal of 
International Business Research 8(1): 39-59.

Dwimartani (2013, Dampak Implementasi IFRS bagi Perusahaan, staff.blog.ui.ac.id.

Epstein, B. J. 2008. The Economic Effect of IFRS Adoption, The CPA Journal : 26-31.

Fosbre, A. B., E. M. Kraft., and P. B. Fosbre. 2009. The Globalization of Accounting Standards: IFRS Versus US GAAP, Global Journal of Business Research 3(1): 6171.

Girbina, M., M. Minu, S. Bunea., and M. Sacarin. 2012. Perceptions of Prepares from Roma nian Banks Regarding IFRS Application, Accounting and Management Information Systems 11(22): 191-208.

Himawan, R. 2010. Persepsi Analisis Laporan Keuangan pada Perusahaan Sekuritas terhadap Penerapan IFRS Secara Penuh. (Tidak Dipublikasikan).

Ho, H. 2008. Spialing Effect of Prior Knowledge in Accounting Studies, The International Journal of Learning15(4): 25-29.

Hyorinna (2013), "Makalah Akuntansi IFRS". HyorinnA2.blogspot.com

Ionascu, M., and I. Ionascu. 2012. The Use of Accounting Information by Financial Analysts in Emergent Markets: The Case of Romania, Accounting and Management Information Systems 11(2): 174-186.
Irdan, 2014. Peneratan IFRS di Indonesia Manfaat dan Kendala, Blog. irdam.blogs.unhas.ac.id

James, M. L., and C. Blaszczynski. 2010. Accounting Students Perceptions of International Financial Reporting Standards, Journal for Global Business Education 10: 37-49.

James, M. L. 2011. Integrating International Financial Reporting Standard Into Accounting Curriculum : Strategies, Benefits and Challenges, Academy of Educational Leadership Journal 15: 127-141.

Kabir, M. H., F. Laswad., and M. A. Islam. 2010. Impact of IFRS in New Zealand on Accounts and Earning Quality, Australian Accounting Review 20(4): 343-357.

Larson, R. K., P. J. Herz, S. Y. Kenny. 2011. Academics and the Development of IFRS: An Invitation to Participate, Journal of International Accounting Research 10(2): 97-103.

Kaiser, J. G. 2012. IFRS and US GAAP: Similarities and Differences,

Pricewaterhouse Coopers LLP.

Kim, H. P. 2011. Investigating Perceptions Concerning the Adoption of International financial Reporting Standards (IFRS) Among College Students. Thesis. Texas Tech University. 
Koh, M. Y., and H. C. Koh. 1999.

The Determinants of

Performance in an

Accountancy Degree

Programme, Accounting

Edcation 8(1): 13-29.

Martani, Dwi, 2014," Dampak

Implementasi IFRS; dampat

Implementasi IFRS bagi

Perusahaan"

staff.blog.ui.ac.id/martani/p

endidikan. 6 Novenber.

Notoatmodjo, Soekidjo, 2003.

Metodologi Penelitian Kesehatan.

Jakarta : Rineka Cipta.

Rutoto, Sabar. 2007. Pengantar

Metedologi Penelitian.

FKIP: Universitas Muria

Kudus

Sugiyono. 2011. Metode Penelitian

Kuantitatif, Kualitatif, dan

$R \& D . \quad$ Bandung:

AFABETA, cv

Wartawarga. 2012, "Sekilas tentang IFRS" student journalis, UG, Juni, 25.

Widaningrum, Agung Praptapa,

Permata Ulfah (2010),

"Pengaruh Ketersediaan

Sarana Pendidikan Dan

Kecerdasan Emosional

Terhadap Tingkat

Pemahaman IFRS Dengan

Minat Sebagai Variabel

Moderating Di Fakultas

Ekonomi UNSOED”.

Simposium Nasional

Akuntansi Purwokerto 